\title{
Preparing future food system planning professionals and scholars: Reflections on teaching experiences
}

Principal authors:

Wendy Mendes, School of Community \& Regional Planning, University of British Columbia

Joe Nasr, Centre for Studies in Food Security, Ryerson University

With contributions from:

Timothy Beatley, Branden Born, Kristina Bouris, Marcia Caton Campbell, Jerome Kaufman, Barbara Lynch, Kami Pothukuchi, Gerda Wekerle

Submitted 7 May 2011 / Accepted 6 October 2011 / Published online 21 December 2011

Citation: Mendes, W., Nasr, J., with Beatley, T., Born, B., Bouris, K., Caton Campbell, M., Kaufman, J., Lynch, B., Pothukuchi, K., \& Wekerle, G. (2011). Preparing future food system planning professionals and scholars: Reflections on teaching experiences. Journal of Agriculture, Food Systems, and Community Development, 2(1), 15-52.

http://dx.doi.org/10.5304/jafscd.2011.021.022

Copyright (C) 2011 by New Leaf Associates, Inc.

\begin{abstract}
This article fills a gap in knowledge related to the preparation of future food systems professionals and scholars. Specifically, the article explores

\section{Principal authors:}

Wendy Mendes, School of Community \& Regional Planning, University of British Columbia, \#433-6333 Memorial Road, Vancouver, BC V6T 1Z2, Canada;

mendesw@interchange.ubc.ca

Joe Nasr, Centre for Studies in Food Security, Ryerson University, 350 Victoria Street, Toronto, Ontario, M5B 2K3, Canada; jinasr@,ryerson.ca

Wendy Mendes, $\mathrm{PhD}$, is adjunct professor at the School of Community and Regional Planning, University of British Columbia Vancouver, Canada. She is also research associate at the Centre for Studies in Food Security at Ryerson University, instructor at Ryerson's Certificate in Food Security, and social planner for the city of Vancouver, Canada.
\end{abstract}

challenges and opportunities encountered by educators who teach food systems courses in university settings. The topic of food systems has recently experienced a boost in acceptance as an area of academic inquiry and legitimate professional practice. The article presents seven firsthand accounts by university educators who reflect back on their early experiences teaching courses on food systems in the discipline of urban planning. Set within a specific global region — North America - the findings are relevant to other

Joe $\mathrm{Nasr}, \mathrm{PhD}$, is an independent scholar, lecturer and consultant, associated with the Centre for Studies in Food Security at Ryerson University, Toronto, where he is one of the coordinators of the Carrot City initiative. He teaches at Ryerson's Certificate in Food Security and has taught planning courses in universities in several countries. He is also cocoordinator of MetroAg-Alliance for Urban Agriculture. 
professions and academic disciplines grappling with the topic of food systems. The analysis points to tensions and opportunities related to the professionalization of this emergent field of research and practice.

\section{Introduction}

The motivation for writing this article stems from discussions between the two principal authors, Joe Nasr and Wendy Mendes. Both Joe and Wendy have taught university-level food systems planning and/or urban agriculture courses since 2005. ${ }^{1}$ Our courses have included both undergraduate courses and graduate seminars in face-to-face and internetbased formats. Early conversations about this topic revolved around changes we have observed regarding the willingness (or lack thereof) of different universities to mount courses on food systems topics, as well as around dramatic changes that we have encountered over the years in the knowledge and first-hand experience that our students bring to class; and of course, around our own pedagogical changes in response.

We quickly noted that a number of our colleagues in planning ${ }^{2}$ programs across Canada and the United States who were also early adopters of food systems as a topic of instruction, would surely have similar observations. It was from these realizations that we felt that documenting the early experiences

\footnotetext{
${ }^{1}$ Wendy Mendes first co-taught, at the School of Community and Regional Planning at the University of British Columbia, Vancouver, Canada, the course "Food Systems Policy \& Planning" in 2005 (with Kristina Bouris — see her reflections later in this paper), and since then has continued to offer it alone. Joe Nasr includes an emphasis on urban food systems in several courses he has taught that deal with urban sustainability and environmental planning, at Bryn Mawr College, the University of Michigan, the University of Toronto, and the University of Western Ontario. They also coteach several courses at Ryerson University (Dimensions of Urban Agriculture in Wendy's case, Urban Food Security and Understanding Urban Agriculture in Joe's case), although those who take these courses are not exclusively planning students.

${ }^{2}$ We are focusing here on urban, rather than regional or rural, planning. How food system considerations fit in regional planning or within the work of rural planners would differ from the examples cited in this paper, though many issues would be in common.
}

of university educators would serve as an important point of reference as we move forward into what is certain to be an era of unprecedented complexity for food system research and practice.

The paper begins with an overview of how food systems came to be decoupled from - and recently reconnected to - urban and regional planning. The approach used in this article is outlined next, along with a quick sketch of the seven experiences of university educators who here reflect on their early experiences teaching courses on food systems within the planning discipline. This is followed by an analysis of key themes and findings from the seven first-hand accounts that were commissioned from these educators (see appendix). The paper concludes with some thoughts on what this may suggest about current and future training for food systems professionals and scholars.

\section{Food as an Urban and Regional Planning Issue}

Historically, cities and their food systems have been tightly linked, with urban populations depending on contiguous food production and distribution systems to sustain themselves (Steel, 2008). Even at the peak of the Industrial Revolution, these ties remained intimately connected, as exemplified by the intensive productive activities found in and around major cities of Western countries well into the first years of the twentieth century. ${ }^{3}$ It is thus not surprising that several of the founders of the planning profession as it has come to be known today did not ignore the question of the food system in the theories they developed involving planned urbanization. We can cite here Ebenezer Howard's Garden City (as the name itself implies), Patrick Geddes' foundational ideas on regional planning, and Frank Lloyd Wright's Broadacre City, to remind us of the centrality of the question of food systems in the thinking of early planning theorists.

\footnotetext{
${ }^{3}$ For historical examples of urban agricultural activities, see Linder and Zacharias (1999) for Brooklyn, New York; Stanhill (1976) for Paris; and Lawson (2005) for American community gardens.
} 
However, intensive rural-to-urban migration over the latter half of the twentieth century, combined with the rise of technologies including mechanized farming, long-distance food transportation, refrigeration and food processing, have resulted in the loss of local farmland and dramatic changes in land use patterns (Mougeot, 1994; Pothukuchi \& Kaufman, 1999). The result has been a separation between cities and their food systems.

There are many signs that this disconnect is starting to be repaired. One indication is the existence of municipal food system instruments in a growing number of Canadian and US cities. Currently, Canadian cities with municipal food policy mandates (such as local food procurement requirements) and/or food policy councils 4 include Toronto, Ottawa, Kamloops, and Vancouver. In addition, food-policy initiatives led by nonprofit organizations, Social Planning Councils or Health Authorities now exist in almost every Canadian province and territory. American cities considered to be food policy innovators include Berkeley, CA, Portland, OR, Knoxville, TN, and Hartford, CT. Estimates are that over 100 cities, counties, regions or states in the US and Canada have established food policy groups to provide a systematic focus on food planning issues. ${ }^{5}$

\footnotetext{
${ }^{4}$ A food policy council (FPC) is an officially sanctioned voluntary body comprised of stakeholders from various segments of a state/provincial or local food system. FPCs are collaborations between citizens and government officials that give voice to food-related concerns and interests. FPCs are asked to examine the operation of a local food system and provide ideas or recommendations for how it can be improved (Iowa Food Policy Council, 2005, 1; Dahlberg, 1994). For a comparative multicountry study of FPCs, see Schiff (2007).

${ }^{5}$ Around 100 food policy groups at the local, county, regional, or state level now exist in the United States alone, not all of them officially organized as councils under or within specific government jurisdictions. Some are networks, coalitions, etc., and may not have any formal relationship to government other than their interest in influencing food and agriculture policy (personal communication, Mark Winne, Food Policy Council Program Director, Community Food Security Coalition, 15 Nov. 2008). In the Canadian context, the People's Food Policy Project (2009) documents dozens of food policy organizations currently active at municipal, provincial, and federal levels. See
}

Food system issues affect the ways that people in cities produce, obtain, consume and dispose of their food. Food decisions impact whether opportunities to grow food in the city are supported, whether a city's most vulnerable populations have access to nutritious and affordable food, whether neighborhoods have grocery stores or farmers' markets within walking distance, or whether domestic waste will overwhelm municipal landfill capacity. Recent decades have seen increased municipal support for food-related initiatives (IDRC \& UMP, 2003; Mendes, 2006, 2007, 2008), which can include creation of new community gardens, use of farmers' markets as catalysts for neighborhood development, siting of food outlets in order to serve lower-income groups, introduction of community kitchens, adaptation of emergency food programs into multifaceted food-security responses, promotion of food-waste diversion strategies, and nurturing of food policy councils.

These types of initiatives have a host of implications for planners, and they align with their roles and responsibilities (Quon, 1999). The attention now being paid to food system issues by planners fits as part of the emergence of strong interest in such issues by a range of urban professionals including architects and landscape architects (Centre for Studies in Food Security, 2008; Gorgolewski, Komisar, \& Nasr, 2011; Komisar, Nasr, \& Gorgolewski, 2009; Viljoen, Bohn, \& Howe, 2005). ${ }^{6}$

A growing number of planning scholars and practitioners are developing food as a specialty, engaging in food planning research, writing new publications on the subject, and developing university courses that focus on aspects of the food system. The claim that food is a legitimate area for planner intervention has been strengthened through several plans and publications since Pothukuchi and Kaufman's observations about planning having overlooking food systems (1999).

http://www.peoplesfoodpolicy.ca/canadian-food-policyorganisations

${ }^{6}$ See also www.carrotcity.org. 
In 2004, two special issues on food planning appeared in planning journals, Progressive Planning and the Journal of Planning Education and Research. Subsequently, food systems have gotten increased attention as a somewhat regular topic in planning journals.

Within universities themselves, the rapid adoption of courses focusing on food systems is now starting to transition to the creation of new academic positions with a specific focus on food systems research and practice. York University (Toronto, 2007), Maryhurst University (Portland: OR, 2011), and the University of Michigan (Ann Arbor, 2011), have hired - or are in the process of hiring - faculty members with a food systems background to complement existing programs in planning, environmental studies, and related fields. The creation of these positions signals a shift in the perceived legitimacy of food systems issues, and their importance as aspects of the professional formation of future planners and related practitioners.

Evidence of growing interest in food issues among planners can also be seen in the creation of two email listservs, both emerging after planner conferences. One, consisting of approximately 350 planners, academics, and practitioners, has been in existence since March 2005 (Foodplanning, n.d.). Another is a community of practice of about 100 planners created after the World Planners Congress in Vancouver in 2006 (Planning for Agriculture \& Food Network, n.d.; Planning for Food, 2006).

At the level of professional associations, food as a planning issue is getting acknowledged more systematically, as illustrated by the American Planning Association (APA). The 2005 APA Annual Meeting marked the first time that dedicated food-planning sessions were organized. Food systems were covered in APA publications for specific audiences, including the newsletter of the Environment, Natural Resources, and Energy division (Kaufman \& Glosser, 2006b) and the newsletter of planning commissioners, The Commissioner (Kaufman \& Glosser, 2006a). A food planning White Paper was developed in 2006 (APA
Food System Planning Committee, 2006) and the subsequent Policy Guide on Community and Regional Food Planning received formal approval in April 2007 (APA, 2007). In September 2008, the APA released a Planning Advisory Service report on Community and Regional Food Planning (Raja, Born, \& Kozlowski-Russell, 2008), followed by one on Urban Agriculture (Hodgson, Campbell, \& Bailkey, 2011). The APA is also currently undertaking a project to "identify and evaluate...food access goals in comprehensive and sustainability plans across the US... [and] provide policymakers and planners with case examples of innovative food access goals and policy development" (American Planning Association, 2011).

The recognition by the APA of food system planning marks a significant shift in the perceived legitimacy of food as a planning issue in North America and elsewhere. This trend is getting stronger. A proposal for a standing interest group in AESOP (Association of European Schools of Planning) was accepted, leading to conferences on food system planning in the Netherlands in 2009 and in the UK in 2010 and 2011. Add to that the inclusion of food as a topic of community plans either as a sole focus or as a component or consideration in larger plans - and it is clear that food is now on the planners' table.

Reasons cited for the heightened awareness among planners of the significance of the food system include the great amount of land used for food system activities, the rising incidence of hunger and obesity, the place of the food system in community and regional economies, the challenges of accessing healthy foods in low-income areas, and the continued loss of farmland in metropolitan areas at the same time that a movement for local food is growing (APA, 2007). Significantly, the reasons cited for engaging in food system planning often contain inflections of sustainability concerns, such as global food "insecurity," high emissions due to long-distance food transportation, loss of farmland, the rise of diet-related diseases, and other global food system vulnerabilities. This points to food policy as an issue with many dimensions: local (e.g., grocery store location, food waste disposal, 
opportunities for urban agriculture, emergency food distribution, development of the local food economy); regional and national (e.g., public health, nutrition, agriculture, natural resources, fisheries); and global (e.g., international trade agreements, impacts of climate change on agriculture) (Dahlberg, 1999).

This range of issues and geographies points to the central significance of globalization in food system issues, while the issues still often remain firmly rooted in the immediate concerns of people's home communities. Attention to the immediate concerns of citizens is reflected in the common association of food system issues with strong citizen participation, inclusiveness, and crosscutting approaches to improved quality of life that bring simultaneous benefit to the economy and environment, and to nutrition, food security and public health (Argenti, 2000; Bouris, 2005; FAO, 1998, 2000; Mendes, 2007, 2008; Rocha, 2001; Smit, Nasr, \& Ratta, 2001; Wekerle, 2004; Welsh \& MacRae, 1998).

Many cities in the global south have for many years been proposing solutions to urban food system vulnerabilities, often in response to crisis levels of hunger and poverty. ${ }^{7}$ While the development of analytical frameworks to facilitate comparative research and information sharing between cities in the developed and developing world is paramount - given the lack of data available to assess different processes, mechanisms, and outcomes for the purposes of this paper, a close examination of urban food system issues in the developing world is beyond the scope of this project. Similarly, while a growing literature on food systems planning is emerging in Europe, ${ }^{8}$ Australia, and elsewhere, the emphasis in this paper will be on the North American context, which is sufficiently distinctive to warrant attention on its own.

\footnotetext{
7 See, among others: Argenti (2000); Dubbeling (2001); FAO (1998, 2000a, 2000b); IDRC and UMP (2003); Lang (1999); Mougeot (2000); Rocha (2001); Ratta \& Nasr (1996).

${ }^{8}$ One center of interest in food systems from a planning perspective can be found at Cardiff University in the U.K. See for instance Morgan, Marsden, and Murdoch (2006) and Morgan and Sonnino (2008).
}

Moreover, although an urban emphasis is maintained in this article, planning for food systems in rural regions is also vital; but the context for rural planning differs substantially from urban areas and it responds to very different needs, though complementarities in planning for urban and rural regions clearly exist. It is hoped that others will take on the challenge of considering questions around the pedagogy of food systems planning in rural areas and in other world regions.

By focusing on the concerns around urban food systems, in a specific global region, this paper examines in detail the pedagogical challenges and opportunities associated with a topic that, although gaining acceptance, remains contested and far from universally accepted as a legitimate activity for the planning profession. In this way, the findings of the analysis are transferable to other nascent issues that are being addressed in education and practice in planning and other urban-focused disciplines, although still in positions of relative marginality.

One of the benefits of reflecting back in time, if only five years, is that it provides the opportunity to consider how much has changed in a relatively short period of time. What is clear is that the rapid transformations in planning knowledge and pedagogy suggest that the food-systems issue for urban planning and related disciplines is set to evolve even further in coming years and decades. One way to document and examine the challenges and opportunities inherent in the professionalization of this emergent field ${ }^{9}$ is through first-hand accounts by planning educators who have taught courses on food planning. It is to these first-hand accounts that this paper now turns.

\section{Reflections of Food System Planning Educators}

Contributors were invited by the principal authors of this article to provide a 1000-word reflection on their early experiences related to teaching about food system issues. Contributors were selected on

\footnotetext{
${ }^{9}$ For an analysis of this professionalization, including examples of individual designers and planners who are now specialized in food systems, see Nasr and Komisar (in press).
} 
the basis of representativity and convenience. 10 The purpose of the focus on early teaching experiences was to highlight the contours of transformation over time in pedagogy, as well as the resistance (or lack thereof) from colleagues and administrators at the universities within which the courses were taught. Each contributor was provided with the same broad set of overarching questions.11 Contributors were encouraged to

${ }^{10}$ While convenience sampling has limitations where replication and extrapolation are concerned, in the case of this study it is an appropriate methodological decision for the following reasons. First, due to the specificity of the topic, the total pool of possible contributors is relatively small. The contributors were among the few early teachers of food system courses in planning schools. Even if a randomized methodology were adopted, it would likely have yielded similar — if not the same - participants. In this sense, a targeted approach is appropriate. This is not to suggest that issues of underrepresentation should not be considered in future studies. Second, the stated purpose of the study is exploratory, making controlled, random sampling less relevant. Third, the contributors were known to the principal authors, who considered the particular experience of each one worthy of inclusion and analysis. Moreover, these experiences were meant to represent specific profiles that the principal authors felt appropriate for highlighting; thus the selection was not random and based on convenience alone.

11 The questions were:

- What is the title and main focus of the food course you taught (or teach), and was it (or is it) taught in a planning school or another department?

- How did you come to propose and teach the course? What or who inspired you?

- What specific contributions do you feel it makes to the planning curriculum and to preparing the planners of tomorrow? Are there other benefits?

- How did you "sell" the course? Was it a struggle to mount it? Was it a challenge to attract students? If so, please tell us about these or other challenges.

- Because food is a nontraditional planning issue, did you (or do you) adjust your teaching methods? If so, how and why? Is there anything about the topic itself that changed your pedagogical approach? Did you seek to treat it (or make it appear) as a traditional planning issue?

- How do you feel the course is perceived by colleagues and students in your planning school or department? Does it complement other offerings in your planning school or faculty? Do you think it has broadened perceptions about emerging planning issues?

- How would you describe the pre-existing knowledge of your students of food issues? Were you teaching to the converted? respond to those questions that most strongly resonated with them. In addition, depending on their particular experience or position in academia, each contributor was given additional specific questions to consider in their response.

The intention was not to conduct a standardized survey. Rather, a qualitative methodological approach was taken, with the aim of highlighting the unique contexts and narratives of the contributors, and allowing themes to emerge that may have been missed in a more empirical approach. Together, the contributions provide a rich set of first-hand insights on a number of benefits and challenges related to teaching emerging planning issues to future planners. The full contributions are provided as an appendix to this article, to provide the full reflections in the authors' own voices. In this section, we will briefly outline the settings for these seven experiences. This will be followed in the next section by a synthesis and analysis of key themes from the seven contributions.

- Gerda Wekerle, Professor in the Faculty of Environmental Studies and Coordinator of the Planning Program, York University, Toronto: Gerda Wekerle describes the Faculty of Environmental Studies (FES), her base at York University, as an early adopter of teaching and research on "emergent" public policy issues that require an "interdisciplinary bridging of fields and disciplines." In keeping with this lineage, Wekerle cites food studies as one in a series of topic areas that were not yet on the broader public agenda when first embraced by FES. Wekerle credits FES's interdisciplinary, "student-centered" approach to learning with the ability to create an environment in which students can innovate by incorporating food issues into papers, projects, and internships, as well as the ability to blur the boundaries between academic research and activism. Of particular interest to Wekerle are the strong partnerships and collaborations between the university and food-focused community services agencies that have resulted from this approach. 
- Jerome Kaufman, Emeritus Professor, Department of Urban and Regional Planning, University of WisconsinMadison; and Marcia Caton Campbell, Milwaukee Program Director, Center for Resilient Cities: Jerome Kaufman's role ${ }^{12}$ as a pioneer in the study of emergent planning issues that took time to become recognized within the field, can be traced back several decades. For Kaufman, his collaboration in 2001 with Marcia Caton Campbell to teach the first class on community food planning in the Department of Urban and Regional Planning, University of Wisconsin-Madison (UWM), marked yet another foray into a topic that was, at the time, "decidedly on the back burner of planning practitioners.” Like Wekerle, Kaufman and Caton Campbell note strong connections between food systems and community-based service initiatives, including student-led community food assessments and other forms of food-related service learning. Reflecting on ten years of food systems planning at UWM, Kaufman and Caton Campbell note the number of students who have "carried their food planning interests into their professional lives as planning practitioners and consultants." They also reflect on the opportunities presented by the topic of food systems to facilitate interdisciplinary research and practice.

- Kami Pothukuchi, Associate Professor of Urban Planning, Wayne State University:

Kami Pothukuchi insists that the topic of food offers an exemplary means for planning students to understand the "interdisciplinary and multi-systems nature of urban policy/planning issues." Pothukuchi's experience teaching a "Cities and Food" course in the urban planning program and researching food systems topics at Wayne State University evolved from her experience studying food topics as a

\footnotetext{
12 This contribution represents both Jerome Kaufman's personal reflections and joint reflections with his former colleague Marcia Caton Campbell, due to their close collaborations on design and delivery of food systems courses.
}

graduate student, then later as a visiting faculty member at the University of WisconsinMadison, where she co-taught a graduate seminar on urban food systems with Jerome Kaufman. While emphasizing the many opportunities presented by food systems teaching and research - in particular, an inclination towards community-based service learning Pothukuchi identifies a number of "structural challenges" that continue to impact her work in the field of food systems planning. She notes difficulties attracting outside research funding, challenges for junior faculty in embracing what remains a "non-traditional" planning topic, and the considerable time required to maintain partnerships meaningfully with community organizations.

\section{- Branden Born, Associate Professor,} Department of Urban Design and Planning, University of Washington: Branden Born combines the perspectives of student, researcher, and teacher in food system planning. Discovering the topic as a graduate student in the previously mentioned seminar taught by Kaufman and Pothukuchi at the University of Wisconsin-Madison in 1996, he saw the need to incorporate food systems into planning curricula. The experience "solidified my interest in offering such a class at my eventual home institution, the University of Washington," where he now teaches "a regular biannual class entitled Urban Planning and the Food System." While cautious at first in emphasizing his interest in food issues as a new planning faculty member, he found relatively little resistance in his college and department to this interest, which was seen as valuable. His regular class now contributes in several ways to the departmental curriculum, filling a demand niche. Ultimately, Branden found that his primary interest and focus on planning process "has been nicely manifested in my food system studies" and "my experience as a student helped me in developing the course and building legitimacy in my expertise in the subject area." 
- Kristina Bouris, Community Planner, City of Victoria, British Columbia: Kristina Bouris was a newly minted planning school graduate in 2005 when she co-taught (with Wendy Mendes) the first graduate course in food systems policy and planning offered at the School of Community and Regional Planning (SCARP) at the University of British Columbia, asking two central questions: (1) What can local government planners do to facilitate local food systems?, (2) What does it take to get the food system on the municipal agenda in the first place? Bouris identifies a number of enabling factors that led to the course being offered in the first place, such as SCARP's mission to "advance the transition to sustainability planning" (of which food systems were understood to play a part), and a (now former) director and faculty member who supported that mission. As with Wekerle's experience at York, Bouris also points to the culture of "innovation and experimentation" at SCARP, where there was pre-existing experience mainstreaming other non-traditional planning issues. Bouris also cites the uniqueness of having a group of graduate students interested in sustainability and food issues who effectively lobbied the School Director for the course.

- Timothy Beatley, Teresa Heinz Professor of Sustainable Communities, Department of Urban and Environmental Planning, School of Architecture, University of Virginia: Timothy Beatley began teaching in 2006 (with Tanya Denckla Cobb) a community food systems class at the University of Virginia that is now regularly offered. The course combines "substantive introduction to the theory and practice of community food planning" with "hands-on workshops" that apply ideas and theory to the local region. In keeping with the experience of other contributors, Beatley's combination of theory with applied practice has resulted in real world applications and outcomes, including community food assessments, policy recommendations, and other "beyond class" outcomes, including the creation of a new local food organization. Beatley reflects on the extent to which sustainable food systems and community food systems are powerful avenues for "teaching about community sustainability and sustainable place-making." "Food," Beatley insists, "provides entry to every aspect of community sustainability." Ultimately, "reinvigorated local sustainable food systems represent a potentially powerful form of community building, and a way to profoundly strengthen and revive our place commitments."

- Barbara Lynch, Professor, Sam Nunn School of International Affairs, Georgia Institute of Technology (formerly at Cornell University): Barbara Lynch came to teach about urban and rural food system issues through Cornell University's Rome Program. The program serves undergraduate students in architecture, art, and planning, with a small number from the humanities and social sciences. Lynch describes how in-depth neighborhood-based research on food topics in an international setting, through a planning workshop she offered in 2006, allowed students to consider not only the specificities of Rome food system issues and challenges, but to transfer this knowledge to consider food system issues in other global contexts as well. Of particular interest to Lynch is the issue of inequal access to good quality food - a truly international issue - which served as a key entry point and organizing issue for the course. Lynch believes that through the course students "gained a new consciousness about the centrality of food to national culture, social integration, and well-being."

\section{Key Themes and Findings}

One of the primary reasons for documenting and analyzing the early experiences of university educators who teach food systems issues is to identify challenges and innovations as we move forward into an increasingly complex global context for food system research and practice. By reflecting on the recent past, and the issues 
Table 1. Themes Emerging from Contributors' First-hand Narratives: Connections Between Teaching About Food Systems and Related Issues

\begin{tabular}{|c|c|c|c|c|c|c|c|}
\hline & Wekerle & $\begin{array}{l}\text { Kaufman/ } \\
\text { Caton } \\
\text { Campbell }\end{array}$ & Pothukuchi & Born & Beatley & Bouris & Lynch \\
\hline $\begin{array}{l}\text { Awareness of difference and } \\
\text { diversity }\end{array}$ & & & $\checkmark$ & & & & $\checkmark$ \\
\hline $\begin{array}{l}\text { Stakeholder involvement in } \\
\text { planning processes }\end{array}$ & & $\checkmark$ & & & & $\checkmark$ & \\
\hline $\begin{array}{l}\text { Awareness of broader } \\
\text { governance context of planning }\end{array}$ & & $\checkmark$ & & & & $\checkmark$ & $\checkmark$ \\
\hline $\begin{array}{l}\text { Links between globalization } \\
\text { and planning education }\end{array}$ & $\checkmark$ & & $\checkmark$ & $\checkmark$ & $\checkmark$ & $\checkmark$ & \\
\hline $\begin{array}{l}\text { Connections drawn between } \\
\text { food systems and sustainability } \\
\text { principles in planning }\end{array}$ & $\checkmark$ & & $\checkmark$ & $\checkmark$ & $\checkmark$ & $\checkmark$ & \\
\hline
\end{tabular}

encountered, we can better prepare ourselves for current and future training of food systems professionals and scholars. This section of the paper summarizes themes identified by contributors that emerged from their early teaching experiences. Table 1 summarizes connections between teaching about food systems and related issues which contributors felt provided further context or enrichment to their pedagogical approaches.

Two themes almost unanimously addressed by contributors were the links drawn between education on food system planning and the issues of globalization, and the issues of sustainability. This is worth reflecting on, in light of the increasingly complex geographical, cultural and socio-political environments in which food system issues are addressed by planners and others. Awareness of issues related to globalization combined with adoption of principles that underlie sustainability thinking, as well as development of inter-cultural skills as a core competency of food system professionals, can be expected to be central as urbanization becomes even more complex and fragile. Born states: "As a field, planning is designed to consider the long-term perspective. As sustainability and large issues such as global climate change and global health come to the fore, planners need to be aware of the sea change and move beyond limited considerations of land use or design and begin applying those skills to a broader set of more global considerations." For Bouris, the sustainability framework for her course "provided the freedom to explore a broad range of subthemes related to the food system."

Beatley concurs that "community food systems are wonderful avenues for teaching about community sustainability and sustainable place-making." He refers to "the power of food as a way of connecting us to place and to making tangible sustainability issues and concerns." Ultimately, for him as for other contributors to this article, "reinvigorated local sustainable food systems represent a potentially powerful form of community building, and a way to profoundly strengthen and revive... our collective commitments to the landscape and community that ultimately sustains." 
Interdisciplinarity and innovation ${ }^{13}$ will be required to address emergent societal issues. Pothukuchi begins her contribution with this statement: "Food offers an intuitive and immediate feel for the interdisciplinary and multi-systems nature of urban policy/planning issues." Reflecting on the experience of York University's FES, Wekerle remarked that "students are decades ahead of the academic community in identifying public policy issues that are emergent and benefit from an interdisciplinary bridging of fields and disciplines, as seen particularly in the fast-growing area of food studies." Bouris uses the example of the range of guests in the class she co-taught — including a policy planner, social planner, neighborhood planner, land-use planner, rural planner and environmental planner - to show that "the food system cuts through the silos of traditional municipal planning practice."

Moreover, numerous students (many of whom are activists on and off campus: Wekerle observes that "FES has tended to attract activist students who have a commitment to community service"14) expect that their work will consist of applied action research. The confluence of research and practice is particularly fertile within food systems issues, and the pedagogical context of planning schools is especially well suited as a setting for this confluence. In Born's case, the service learning approach was reflected in the major assignment, "a client-driven paper that assisted a local food system entity." The integration of "service learning" into Kaufman and Caton Campbell's teaching offers another good example, with students "contributing ten hours of volunteer time to a food-related

\footnotetext{
13 A number of pioneering studies that have been emulated by community and governmental organizations were undertaken by planning students within a class setting. Three can be cited for illustration: the study of food security in Los Angeles led by Bob Gottlieb at Occidental College in the mid-1990s; Kaufman and Pothukuchi's studio at the University of Wisconsin-Madison in 1996; and the Diggable Cities study at Portland State University in 2005-2006, a pioneering inventory of land potentially usable for urban agriculture.

14 This differs from Pothukuchi's experience, in which only a small minority of students in her Food and Cities course tend to be activists.
}

community organization over the course of the semester and writing reflectively upon that work." Similarly, Beatley states that "food courses and teaching... seem especially potent as community catalysts." He observes that, after a presentation by students of findings from their course at Charlottesville City Hall, "the group in attendance collectively shrugged 'what do we do now' and on the spot, a new local food organization was hatched. Called E.A.T. Local (Everyone at the Table), this group met for several years, and continues to function as an important virtual community and communication vehicle, helping to hatch a number of local food projects and initiatives." In the case of Pothukuchi's experience at Wayne State with her "Cities and Food" course, after it struggled in its initial years to attract enough students, only after she strengthened the servicelearning aspects of the course in 2008 did it develop consistent enrolments from students from a range of departments.

At the same time, exposing students interested in food concerns to "faculty members whose primary expertise is not food studies but... [who] have been supportive of student work on food and agriculture...pushes the boundaries of food studies while, at the same time, developing broad support for it." Thus, "food and agriculture studies have been...mainstreamed rather than enclaved into a designated program or department" (Wekerle). Kaufman and Caton Campbell similarly observe, "community food planning offered synergies in research and professional collaboration with colleagues from other departments."

In addition to the themes identified above, other crosscutting themes can be discerned in the seven contributions - themes that relate to the pedagogical experience itself, its enabling context and its impacts. Some of these concern specific challenges that were confronted in teaching the food planning courses, or, conversely, the opportunities that such teaching opened up. Other themes relate to benefits that teaching about food offer to student learning. Table 2 analyzes some of these additional themes. 
Table 2. Additional key themes identified by contributors: Pedagogical setting, experience and effects

\begin{tabular}{|c|c|c|c|c|c|c|c|}
\hline & Wekerle & $\begin{array}{l}\text { Kaufman/ } \\
\text { Caton } \\
\text { Campbell }\end{array}$ & Pothukuchi & Born & Beatley & Bouris & Lynch \\
\hline $\begin{array}{l}\text { Challenges of legitimacy or } \\
\text { academic credibility for } \\
\text { instructors as a result of } \\
\text { teaching food planning course }\end{array}$ & & $\checkmark$ & $\checkmark$ & $\checkmark$ & & & \\
\hline $\begin{array}{l}\text { Impact of departmental culture } \\
\text { on ability to mount food } \\
\text { planning course (i.e., climate of } \\
\text { innovation or conservatism) }\end{array}$ & $\checkmark$ & $\checkmark$ & $\checkmark$ & $\checkmark$ & & $\checkmark$ & \\
\hline $\begin{array}{l}\text { Ability to "brand" a planning } \\
\text { department as a destination } \\
\text { school for food planning }\end{array}$ & $\checkmark$ & $\checkmark$ & & $\checkmark$ & & & \\
\hline $\begin{array}{l}\text { Impact of "pioneers" in enabling } \\
\text { ability to teach food planning } \\
\text { (i.e., legitimacy) }\end{array}$ & $\checkmark$ & & $\checkmark$ & $\checkmark$ & & $\checkmark$ & \\
\hline $\begin{array}{l}\text { Food planning course resulting } \\
\text { in catalytic effect in community/ } \\
\text { community-building/activism/ } \\
\text { social awareness }\end{array}$ & $\checkmark$ & $\checkmark$ & & $\checkmark$ & $\checkmark$ & & $\checkmark$ \\
\hline $\begin{array}{l}\text { New/wider career paths } \\
\text { introduced to students }\end{array}$ & $\checkmark$ & $\checkmark$ & & $\checkmark$ & & & \\
\hline
\end{tabular}

Table 2 shows that there are recurring challenges, as well as opportunities, across the various experiences shared in this article. The challenges may be largely structural and institutional in nature. Pothukuchi identifies three such challenges:

- Difficulties with obtaining outside funding for research on a new topic that does not squarely fall within traditional funding categories or funders' missions

- Isolation as a junior faculty in a department and university context where colleagues in related interdisciplinary fields were hard to find (say, in public health or environmental studies)

- The nature of an emerging field of practice in which research questions, contextual understanding, and identification of key actors necessitate active involvement in ongoing policy and grassroots efforts, which "posed opportunity costs to time for research and writing."

If, indeed, institutional resistance is not uncommon when launching a course on a non-traditional planning subject such as food system planning, it is pertinent to learn more about such resistances to innovation in academic planning curricula - if for no other reason than to better prepare the faculty member, especially if he or she is junior faculty, for the risks faced in putting forward such a course. Such risks are evident in several of the contributions in this paper. Caton Campbell was "initially discouraged by some of her new colleagues from joining Kaufman in what they viewed as a boondoggle." Pothukuchi notes that, in the early years, faculty colleagues in her department did not recommend (and in some cases, recommended against) her food-focused course to their advisees.

To learn more about these reactions, one would have to dig further into the explanations for such resistance. Why would some faculty members (or 
students for that matter) be opposed, or at least skeptical, about planners reaching into "new" areas such as food? While this paper cannot begin to address such questions (since it is based on experiences of those who taught, not those who resisted the introduction of such teaching into the planning curriculum), it is hoped that other researchers will take on this challenge.

While this paper can only provide indirect allusions to what may explain the marginality of certain areas such as food within the planning profession, we can at least identify some clues from the experiences here shared about what might reduce this marginality. Contributing factors to the shift from doubt to acceptance of food issues in teaching planning include presence of champions in the department, the level of collaboration that takes place to avoid isolation of a "foodie" planner (whether faculty member or student), high level of student interest, potentials that are perceived as assets (for bridging, for funding), and promise for career enhancement (i.e., indications that food is an area that can lead to tenure/promotion). One example of the potential for bridging is shown in the presentation that took place at the end of Kaufman and Caton Campbell's course to an "invited audience of approximately 40 city and county planners, local government officials, professionals working in food-related agencies and nonprofits, and interested students and faculty." Another is the significant food dimensions in some formal partnerships the City of Vancouver recently set up (e.g., Greenest City Scholars, CityStudio).

Several contributors emphasized the use of different pedagogical approaches in their foodfocused courses. The community food systems class Beatley co-teaches works "both as a substantive introduction to the theory and practice of community food planning, as well as a hands-on workshop class applying these ideas and theory to our own local region.” Pothukuchi also highlights "hands-on elements to course delivery, including participant observation by students of the workings of a community-food site."
Food system courses can offer lessons on the place of food in society. Lynch says of the workshop she led in Rome for Cornell students, "all students in the workshop — not just the "foodies" — had a greater appreciation of how food moves from producer to consumer, and what happens to it along the way... On the whole, the class seemed to have gained a new consciousness about the centrality of food to national culture, social integration, and well-being."

Conversely, Bouris emphasizes the relevance of food as a learning instrument for future planners. "The course was designed to use the food system as a vehicle to teach students about the legislative, political and institutional context of local government in Canada, and the tools and techniques available to planners - regardless of the issue at hand. We spent a lot of time on the basics, explaining the roles and responsibilities of local government planners...It is hard to argue that planners should 'do' more for the food system if there is little understanding of what planners 'do' in the first place." For Bouris, "planners need an understanding of complex, high-level, heady issues, as well as a firm grasp of the tools, techniques, processes and dynamics in their midst."

According to Born, his class "contributes to the departmental curriculum in several ways. Primarily, it builds knowledge of food systems for future professionals, offering a marketable skill set and connections for future job opportunities. The class also fills a demand niche; students in our department are very interested in the linkages between planning and the food system. The class has become something that the department can sell as a special offering, making the program more attractive in a competitive landscape of planning schools. Students have also benefited beyond the pedagogy and long-term job opportunities through a variety of funded and non-funded research and teaching opportunities. Finally, the class helps to prepare students to think about the emerging issues for society generally and planning specifically."

The work opportunities offered by food systems courses should not be underestimated in the 
current economic conditions. Pothukuchi points out that "these days in the Detroit region, new graduates are finding more employment opportunities related to community food planning than in practically any other sector; many of our students have successfully taken on such positions or incorporated related elements in their jobs."

\section{Conclusions}

Today, we can conclude that the food system is no longer "a stranger to the planning field," as Pothukuchi and Kaufman claimed in their seminal article on the subject (2000). As Kaufman and Caton Campbell observe, food system research is now "well integrated into the curricula of many planning schools... recognized as an appropriate arena for theoretical inquiry as well as empirical research," and considered important by the professional planning community (Kaufman and Caton Campbell). In their specific experience, Kaufman and Caton Campbell found that "our course was legitimated at the planning department level among its originally skeptical faculty both by the students we succeeded in recruiting to our program and by the community food planning research and activism that we engaged in outside the classroom and in the community."

As a result, the idea that food has a "place on the table" of planning, so to speak, is no longer strange and easily dismissed. This shift has been quite dramatic, in a short time span. This said, however, one should not overstate how far food has managed to entrench itself in training for planning and other urban-focused professions. No one can make the claim that most planning offices nowadays engage in food system planning in the same way that they do, say, transportation planning or land-use planning - a problematic situation, considering that many of the most formidable challenges of urbanization in the current global context, whether climate change, peak oil, or hunger and obesity crises, are undeniably food system issues.

Until food systems become more established as an area of practice, "students have to become welleducated planners who can bring food planning into the planning conversation as food continues to be seen as a critical issue in urbanized areas" (Wekerle). Similarly, Kaufman and Caton Campbell found that, while some students wanted to work specifically in food planning, "most wanted to follow more traditional job paths in planning, but with a desire to expand their prospective colleagues' horizons about the benefits of supporting local and regional food systems."

The central issue in the present paper is not, however, whether we have gone a long way or only a little way in that direction. The focus here is neither planning discourse nor planning practice it is planning pedagogy. The literature that has started to emerge on food in planning has largely not touched on the pedagogical aspects. ${ }^{15}$ Beyond merely examining how food systems are being taken up in planning education, this paper offers additional contributions lacking in the literature. One benefit of our study is its unusual format and perspective. Specifically, it foregrounds first-hand accounts of planning educators who have taught courses on various dimensions of food policy and planning. ${ }^{16}$ This approach allows a richer set of insights to be gained about how and why planning educators have sought to teach food policy, what strategies they used, what professional and institutional challenges they faced, and what benefits their students may have gained.

Food policy provides the opportunity to examine how planning educators may be using such multifaceted issues as vehicles to teach future planners to approach urban problems using a more holistic lens, and to consider the sustainability of the solutions to these problems. For instance, urban agriculture strategies can be undertaken by

\footnotetext{
15 Janet Hammer's JPER article (2004) is a notable exception, but it is a very different paper from this one, as it is based on a survey of course syllabi rather than teaching experiences. 16 Another set of reflections that would be worth exploring in a different paper is the experience of students (both "foodies" already interested in food system issues, and others just discovering the subject) in taking a course focusing on an emerging issue like food for the first time, or even choosing to make food systems their specialization during their planning studies.
} 
planners not only with the goal of strengthening food availability and improving nutrition, but equally to enable social cohesion and economic opportunities for urban gardeners, reduce the distance food travels from seed to table, improve urban air quality, and create vibrant neighborhood gathering places for all citizens (Mendes, 2007, 2008; Mendes, Balmer, Kaethler, \& Rhoads, 2008; Smit, Nasr, \& Ratta, 2001; Wakefield, Yeudall, Taron, Reynolds, \& Skinner, 2007). In this way, multiple uses and multiple outcomes are assumed, as are links between local and global pressures. Because of their inherently interdisciplinary and integrative as well as multisectoral and multi-actor nature, food systems as a planning issue offers a model from which to learn about how best to respond to complexity and diversity in planning problems and their solutions. In raising questions where they apply planning theories and approaches to food, planning students "highlight how food studies can benefit from a broader planning perspective, as well as how planning may be enriched by an emphasis on food and agriculture" (Wekerle).

Together, the combination of historical contextualization, first-hand accounts, and analysis of key themes contribute much needed insights into the challenges and breakthroughs associated with exploring what Bouris refers to as the "delicate forces that create and shape an emerging planning issue" like food systems, and with incorporating it into planning pedagogy and knowledge. 


\section{Appendix: Seven Reflections}

\section{Contribution \#1:}

\section{A Student-Centered Focus on Food: York's Faculty of Environmental Studies}

Gerda R. Wekerle, Professor in the Faculty of Environmental Studies and Coordinator of the Planning Program, York University, Toronto

The Faculty of Environmental Studies (FES), York University took in its first graduate students in 1969. Since then, we have often found that students are decades ahead of the academic community in identifying public policy issues that are emergent and that benefit from an interdisciplinary bridging of fields and disciplines, as seen particularly in the fast-growing area of food studies.

In 2007, we hired our first tenure-stream, full-time appointment to teach courses on food. With agronomy and political ecology in his background, this faculty member, Rod MacRae, was a food systems policy consultant and coordinator of the Toronto Food Policy Council (TFPC). This experience links our students directly to the rapidly evolving and multi-sector Canadian food systems planning community. We now offer three courses on food in FES, at the undergraduate and graduate levels, one of which is Food, Land and Culture.

FES first attracted students to food studies 35 years ago. In 1973, three master's students completed major research papers: Conservation and Foodstuff Production, Basic Soil Ecology and Chemical Fertilizers, and Population Growth and the Problem of Food Supply. From 1973 to 2005, 118 master's students, supervised by more than 20 different faculty members, completed major research papers on a broad range of topics that were integrated into most of FES's key areas of teaching and research. These include student field work on food and agriculture in the Global South, focused on topics such as cooperatives and agricultural development in Tanzania; farming systems and eco-development in dryland Africa; urban agriculture in Jakarta and in Kampala; smallholder coffee production in Indonesia and
Costa Rica; feeding and humanitarian aid in Africa; and food security and refugees. Students focusing on food and agriculture in the Global North have chosen topics that include food policy and community gardens in Toronto; design for rooftop gardens; nutrition and community kitchens; health benefits of school breakfast programs; medicinal plants and community health; migrant farmers; food banks and waste management; educating new farmers in Ontario; and feminism and farming and ethics in agriculture.

A PhD program was introduced in 1991. The first three completed dissertations focused on agricultural biotechnology and the environment, environmental risk assessment of GMO canola, and seed saving. Nine PhD students are currently focused on food issues, including an emphasis on women and food and on farmers' movements in Europe and Latin America.

\section{Leadership and Activism}

FES has tended to attract activist students who have a commitment to community service. As final projects for undergraduate theses and master's research papers, our students have established a number of school gardens, children's gardens, and community gardens in Toronto and its suburbs. The first fair-trade coffee shop in Toronto, Alternative Grounds, started as a final paper by one of our Masters in Environmental Studies students. After FES was gifted a rain forest in Costa Rica as a research centre, Las Nubes, students worked with local farmers to promote shadegrown coffee. Students and farmers developed and marketed a new product that is sold through Timothy's, a Toronto coffee chain, and is widely publicized at the York University coffee shop. 
One of our graduate students developed a curriculum for new farmer training that she tested on interns at organic farms in the region, and which continues to be used. Another graduate student developed a prototype rooftop garden for FoodShare's warehouse in downtown Toronto that evolved into their very successful rooftop foodgrowing area. A group of our students organized an alternative organic food service on the York campus to challenge the prevailing corporate food provider, running it for almost ten years while creating student employment. Our students also persevered to gain administration commitment for a community garden on campus, the Maloca Garden, which is still going strong.

\section{Planning and Food}

Interest in planning and food at FES is relatively recent, emerging since about 2000 . We have a large planning program - about 40-60 masters students every year. In 2003, we graduated the first three planning students whose interests focused on food. One focused on urban growth and agricultural land reserves, the second studied visual media in food system planning, the third studied a rural organization in Mexico that linked farmers and urban consumers. In 2004, three more planning graduate students focused on rural wine tourism and conservation of rural character, faith communities and food justice, and urban agriculture in Havana and Toronto. In 2006-2007, about six planning students focused on food and agriculture. About one-third of the students in the planning program (and a sixth of the masters students in FES) currently concentrate on food issues.

Within the planning program, students have incorporated food and agriculture interests into studio projects. For example, the redevelopment proposal for a military housing site near the university included a plan for a community garden and farmers' market. A studio that developed a plan for a city public works site incorporated land for a market garden and farmers' market.

Students have also benefited from international research opportunities, such as a long-term project we had in Indonesia in which both Canadian and
Indonesian students focused on urban agriculture. As part of the Canadian Urban Institute's international internships, one student went to Jamaica in summer 2008 to work with a potato cooperative. Two of our MES students have been recipients of the prestigious Agropolis award for graduate study from the International Development Research Centre in Ottawa. Our graduates have formed the backbone of the food security and urban agriculture movement in Toronto and other parts of Canada, providing leadership in food agencies and opening up new areas of practice.

\section{How Do You Build a Field When None Exists?}

Prior to the emergence of food studies as a field, the Faculty of Environmental Studies attracted students who had identified food and agriculture as a pressing issue. They had nowhere else to study this area. FES's masters program is structured around student-centered learning: students work closely with a faculty advisor to design their own academic plan that outlines learning objectives and the strategies to achieve them, combined with extensive one-on-one mentoring. Students are able to incorporate food issues into papers, projects and internships, as well as to take courses in other academic units and universities. Through such a student-centered learning program, we have found that students are innovative in identifying emerging issues in food studies. Their research and community projects often contribute innovative approaches and new knowledge.

Food and agriculture studies have been spread throughout our large program and mainstreamed rather than enclaved into a designated program or department. Faculty whose primary expertise is not food studies but areas such as tropical ecology, critical development studies, conservation, health, social movements, and planning, have been supportive of student work on food and agriculture. This pushes the boundaries of food studies while, at the same time, developing broad support for it.

Partnership and collaboration have been important, both with other universities, especially Ryerson and the University of Toronto, and with community 
agencies. For the past seven years, the three universities and the TFPC have jointly organized and funded a yearly speakers' series, Food for Talk, to provide a resource for all our students and a forum for academics and community agencies to meet. Every two years the series hosts a graduate student colloquium on food. Students in FES have benefited immeasurably from on-going and longterm relationships with community agencies such as FoodShare and The Stop Community Food Centre. These have provided opportunities for volunteer work, paid internships, and sites for action research.

Planning students act as a bridge. They bring food issues into planning by introducing these topics in courses that they take and projects that they do. By working at the intersections of planning and other areas of environmental studies, they often raise new issues about planning and urban agriculture. As planning students, they apply planning theories and approaches to food. For instance, how do regional food systems relate to new regionalism debates? How do you plan for more equitable and sustainable food systems? How do you target poverty reduction in rural development? How does communicative planning apply to community food security? Does GIS (geographic information systems) help in identifying sites for food production in the city?

In raising these questions, they highlight how food studies can benefit from a broader planning perspective, as well as how planning may be enriched by an emphasis on food and agriculture. As in other programs, our students struggle with the question of where food fits into the wider planning profession. If they focus on food and planning, where will they find employment? In Canadian cities, only Vancouver is known to have hired a planner specifically to work on food issues, although in other urban areas, such as the Region of Waterloo, planning and public health staff have worked together on strategic plans. In the short term, students have to become well-educated planners who can bring food planning into the planning conversation as food continues to be seen as a critical issue in urbanized areas. 


\title{
Contribution \#2: On Collaboration in Teaching a Food Planning Course
}

\author{
Jerome Kaufman, Emeritus Professor, Department of Urban and Regional Planning, University of \\ Wisconsin-Madison; and Marcia Caton Campbell, Milwaukee Program Director, Center for Resilient Cities
}

Our story is about the value of collaboration when stepping gingerly into virgin, unexplored territory in the planning field. In 1981 one of the authors of this piece, Jerry Kaufman, joined with Elizabeth Howe to teach the first-ever planning ethics class in a graduate planning program. Twenty years later, in 2001, Kaufman entered into collaboration with Marcia Caton Campbell to teach the first-ever class in a graduate planning program on community food planning. At the time each of these courses was offered, similarities were evident. Sparse research had been undertaken in the planning community to draw upon in teaching either subject. Little demand for, let alone interest, existed among planning students and planning faculty for either class to be offered. And both subjects were decidedly on the back burner of planning practitioners.

Yet, in both cases, these two quite different fields of inquiry gradually gained acceptance and legitimacy within the planning community. With planning ethics, which has been around much longer than community food planning, that acceptance is much more apparent. Planning ethics is now well integrated into the curricula of many planning schools, and recognized as an appropriate arena for theoretical inquiry as well as empirical research. And the professional planning community clearly recognizes the importance of ethics through its codes of ethics, which provide guidance for denoting both the aspirations and limits of planner behavior. In contrast, community food planning is still at the seedling stage, but recent signs show that the plant is growing at a healthy pace and becoming more firmly rooted in the planning community.
The circumstances that led to our co-teaching a semester-long community food-planning course are worth considering. In early 1997, Kaufman was asked to head up the Madison Food System Project (MFSP), part of the larger Wisconsin Food System Partnership, a five-year program funded by the W. K. Kellogg Foundation at the University of Wisconsin-Madison (UWM). With little knowledge of the food system, but having a good understanding of cities and regions, Kaufman accepted this challenge with a mix of trepidation and intrigue - trepidation, because he was an outsider to food system work and had a lot of learning to do, and intrigue, because the void in the literature of planning about food issues offered him an opportunity to cover new ground.

Soon after becoming MFSP director, Kaufman decided to combine his new interest in food issues with his role as a planning educator. Since it was his turn to teach the department's required planning workshop in the fall of 1997, he decided to jumpstart the learning process in the food arena by devoting the workshop to a community food assessment of the Madison-Dane County region. This was an ambitious undertaking, given the newness of the subject, but as a senior faculty member Kaufman had considerable range to choose a workshop topic of his liking. With the assistance of Kami Pothukuchi, a visiting assistant professor in the Department of Urban and Regional Planning (URPL) at that time, they undertook this new endeavor. They also joined forces to do some research on the connection between food and planning, and MFSP began to engage in some field projects in the Madison area. Pothukuchi left Madison in the spring of 1998 to 
accept a full-time position in the planning program at Wayne State University.

Marcia Caton Campbell joined URPL in the fall of 1998 as an assistant professor. Hired primarily to teach conflict resolution, she also had a passing interest in food system issues. As a junior faculty member, however, she was initially discouraged by some of her new colleagues from joining Kaufman in what they viewed as a boondoggle. Delighted to discover Caton Campbell's interest, Kaufman soon drew her into the web of MFSP activities as its assistant director. She served as advisor to the MFSP student project assistants and collaborator with Kaufman on MFSP research and communitybased service initiatives. They then began to discuss collaborating on a new course on community food planning. By then, the footing for such a course was more secure, not only among some planning students, but also with students in other campus departments, as interest in strengthening community and regional food systems began to rise. Moreover, Kaufman's colleagues in the planning department, puzzled at first by another of his wanderings into strange territory, began to think that maybe he was on to something.

Planning for Community Food Systems had its initial offering in the spring semester of 2001. Widely advertised across the UWM campus and structured as an introduction to community food planning for juniors, seniors, and graduate students, the course attracted students from diverse fields of study. The 17 -student pool for this initial offering was quite broad: 6 were undergraduates and 11 were graduate students; 3 were URPL graduate students, while the rest came from at least 7 other campus departments; 5 of the 17 were self-described "hardcore foodies," while the remainder were drawn to the course out of curiosity. Kaufman and Caton Campbell were definitely teaching to the interested, but not yet to the converted.

The course combined lectures and discussion about the structure of the food system and food system issues with field trips to community food projects in the Madison area that ranged from a food co-op to community gardens and community- supported agriculture farms. A reader of articles drawn from research literature, newspapers, and magazines as the course textbook was prepared. The growing food systems expertise around the Madison campus and the Madison community was tapped by inviting guest speakers to the class. Students were assessed through a midterm exam on basic food system concepts, reflective responses to field trips, and a final paper on a food issue of their choice. In addition, students engaged in service learning, contributing 10 hours of volunteer time to a food-related community organization over the course of the semester and writing reflectively upon that work. The course was sufficiently well received that the URPL faculty thought it should be offered again, although skepticism lingered about the relevance of the food system to urban and regional planning. At the end of the 2000-2001 academic year Kaufman retired, turning the directorship of MFSP and the teaching of the course over to Caton Campbell.

After reviewing, with Kaufman, the initial offering of Planning for Community Food Systems, Caton Campbell decided to teach the course again in the fall of 2003 solely at the graduate level to avoid content duplication with two undergraduate-level courses in the College of Agriculture and Life Sciences. The course remained structured around lecture, discussion, field trips to Madison area community food projects, and guest lectures by other faculty. This time, 11 of the 13 students in the class were master's students in planning. Seven of the 13 were "hard-core foodies," three of whom chose community food planning as a concentration within the URPL master's program. The seven indicated that they had come to UWM specifically to study food systems, although only a few had significant prior knowledge or experience in the area.

As before, the students wrote a midterm exam and reflective papers on class field trips. This time, however, the service learning component and individual final paper were replaced by a collaborative final project undertaken by the entire class: a white paper exploring ripeness for the formation of a local food policy council. The students ended the 
course by presenting the white paper to an invited audience of approximately 40 city and county planners, local government officials, professionals working in food-related agencies and nonprofits, and interested students and faculty.

Planning for Community Food Systems was offered a third time during Caton Campbell's appointment at UW-Madison, during the fall of 2005. The course again attracted 13 graduate students, now almost all planning students, 6 of whom had come to URPL to specialize in community food planning and most of whom had some prior experience in food systems work. Caton Campbell was now not teaching to the newly converted, but to people with longstanding interest in the area. In addition, by 2005 the food systems literature had developed such that several excellent books could be used as course texts in addition to the standard reader. These recently published works and the students' level of sophistication raised the level of discourse about the food system and its relationship to planning to a much higher level. The course was structured similarly to the 2003 offering; however, this time, the class undertook an ambitious, participatory community food assessment for a Madison neighborhood.

What lessons did we glean from our collaboration? First and foremost, we discovered that a small, but steady, stream of students - roughly one-sixth of the incoming URPL students annually from 2003 on - were not only interested in studying community food planning, but were drawn to the UWM campus and to URPL in particular to satisfy their desire to merge interests in the food system and planning. During the 9 -year period that community food planning flourished at URPL, master's and doctoral students structured their degree concentrations around food, took courses in many other departments around campus to add breadth and depth to their substantive interest, wrote working papers and theses that developed our understanding of the local food system, formed an official student group focused on food issues, and became local food activists in Madison and Dane County. Many of these students carried their food planning interests into their professional lives as planning practitioners and consultants, and as faculty members in other planning programs around the United States (including Branden Born; see his contribution later in this paper).

As Caton Campbell prepared to leave URPL for planning practice at the end of the 2005-2006 academic year, ${ }^{17}$ her students compiled a guidebook of pathways through UWM courses for future students interested in community food planning. These pathways represent multiple avenues through which students might engage in food planning work, by focusing on food and land use, food and the environment, food and community development, food and economic development, and the like.

The second lesson has to do with the reaction of others: our course was legitimated at the planning department level among its originally skeptical faculty, both by the students we succeeded in recruiting to our program and by the community food planning research and activism that we engaged in outside the classroom and in the community. Community food planning offered synergies in research and professional collaboration with colleagues from other departments, including rural sociology, agronomy, and family and consumer science. Our collaborations not only attracted significant numbers of students, but garnered substantial research dollars and support for students.

Third, the collaboration smoothed the waters for Caton Campbell to become engaged in food planning teaching, research, and community service activities. Having Kaufman, as a senior faculty member, "run interference" for her in the department helped other colleagues give her the green light to pursue her multiple interests in community food planning.

Finally, by joining forces, we had the opportunity to mentor students who expressed interest in food

\footnotetext{
${ }^{17}$ Since then, another food system specialist, Alfonso Morales, has joined the URPL faculty, reviving the food stream in that department.
} 
planning and advise them on career paths. Some

wanted to work specifically in food planning. Most wanted to follow more traditional job paths in planning, but with a desire to expand their prospective colleagues' horizons about the benefits of supporting local and regional food systems. In addition, the relationship between Kaufman and
Caton Campbell, with Kaufman serving as a mentor to Caton Campbell at the beginning of her tenure at UWM, soon developed into an equal partnership. We both benefited from the rich give and take of our collaboration, with a productive synergy as the byproduct. 


\section{Contribution \#3: Gaining Tenure Through Food Planning Scholarship}

Kami Pothukuchi, Associate Professor of Urban Planning, Wayne State University

Food offers an intuitive and immediate feel for the interdisciplinary and multi-systems nature of urban policy/planning issues (more so, I think, even than housing). Food is also a basic need, and today's crises of climate change, rising energy costs, homeland security concerns and food safety risks in global sources, and obesity and related health costs are already raising the importance of regional food systems and the indispensable role that planning can play in offering solutions. There is greater urgency for such recognition in other parts of the world, but I believe US planners are moving in this direction. The emerging local food movements, in offering leadership and practical support for planners (and the leadership offered by planners in this movement), are a key resource for food planning.

The course, Cities and Food, is a survey of social policy aspects of food, nutrition, and agriculture and their urban implications, especially (but not exclusively) in the North American context. There are some hands-on elements to course delivery, including participant observation by students of the workings of community-food sites such as a food pantry, grocery store, farm or community garden, farmers' market, CSA operation, etc. This is a course that is offered in the urban planning program to first-year graduate students and upperclass undergraduates. Because of initially insufficient enrollment by urban planning students, the course was actually taught only twice in the program over its first four years, despite being offered almost yearly. In that period, it saw more enrollments by students from outside the planning program. In Winter 2008, it was awarded a sustainability grant by CommunityEngagement@ Wayne, a unit that promotes and facilitates community engagement by students, to develop the service-learning aspects of the course. Since 2008 , it has been taught regularly as a combination of lecture and a seminar series in which community-based "experts" discuss varying aspects of food systems. In 2011, 11 guest speakers visited on an almost weekly basis. The course now sees consistent enrollments from planning, nutrition and dietetics, political science, and other departments.

The "visiting faculty" experience teaching with Jerry Kaufman the graduate planning seminar on urban food systems at the University of WisconsinMadison both motivated and prepared me to offer the course. It underscored for me the urban relationships and impacts of food systems and the role that community and regional planning can play in delivering important goals related to food security, food access, and food system sustainability. As a graduate student, I had taken a course on "World Food Systems," which did inform my later work, but by itself it did not register as a potential focus of teaching in a planning department.

The usual means were used initially — fliers, student advising, and mass emails to students and faculty colleagues within and outside the department Placing the course on the rolls was less challenge than obtaining sufficient enrolment. We face numerous structural barriers to successfully offering new courses, including the fact that our professional graduate program is aimed mostly at returning students, many of whom work fulltime. Courses are offered almost entirely on an evening/ weekend schedule, which means fewer total timeslots (6 or 7) to offer a given number of courses, resulting in scheduling overlap of required and elective courses. Newer content with untested implications for professional planning practice is inherently hard to sell to our program's "target audience" and especially difficult to offer successfully given the scheduling structure. While this 
impacted the Cities and Food course at first, it is no longer true due to more recent economic conditions. These days in the Detroit region, new graduates are finding more employment opportunities related to community food planning than in practically any other sector; many of our students have successfully taken on such positions or incorporated related elements in their jobs. A key challenge in the early years was that faculty colleagues in the department did not recommend this course to their advisees. A couple of interested students reported early in the course's life that they were discouraged from taking the course.

Because planning students have been in the minority, teaching the course has been a bit of a challenge as it was initially structured with more planning content. Now it is more a more general survey of issues/problems and solutions, even though a significant proportion of the papers is written by planners and/or incorporate planning approaches and perspectives. The hands-on element is useful regardless of the student's academic home. Recommendations in student projects completed in 2008 are being implemented in a new program called "SEED Wayne" — Sustainable Food Systems Education and Engagement in Detroit and Wayne State University. Hopefully, as students see their proposals considered for implementation, they will urge others to take the class. Since SEED Wayne started in 2008, its programs have attracted more students to the Cities and Food Class and its visibility — and recognitions it has earned - have led to more faculty acknowledgment of the importance of food issues and direction of students to the course.

There are usually one or two students (in a class of, say, 8 to 10 students) who are activist in their orientation and already involved with community organizations that deal with urban agriculture, food assistance, food rescue, or related issues. These students are distributed equally among planning and other students. For them, the course offers a broader, systems-oriented approach to their involvement and informs their activist approach, even if they are left somewhat confused about what planning is and how it can help.
Although my interests and involvement in local food activities are generally well known in the department, the course itself did not register on the radar screen of planning students or faculty members until the creation of SEED Wayne. This is partly because it was not consistently offered initially, was not part of the regular curriculum, and carried the "generic" number for new and experimental courses. My view is that, initially, faculty colleagues did not perceive this topic to be important for planners to learn about. The course does link to concepts I offer in other courses, such as urban design, community organizing, and planning theory. However, only those students who already have taken or intend to take the other courses benefit from the linkages.

In addition to difficulties with teaching about food systems, I also faced challenges preparing for tenure as someone working on an innovative topic for my research. Among the structural challenges I faced were:

1. Difficulties with obtaining outside funding for research on a new topic that does not squarely fall within traditional funding categories or funders' missions (none of my external grant proposals were funded prior to receiving tenure);

2. Isolation as a junior faculty in a department and university where colleagues in related interdisciplinary fields were hard to find (say, in public health or environmental studies);

3. The nature of an emerging field of practice in which research questions, contextual understanding, and identification of key actors necessitate active involvement in ongoing policy and grassroots efforts. I have found my involvement in the Community Food Security Coalition and in local organizations central to my contributions to planning scholarship but involvement also posed opportunity costs to time for research and writing. Plus, my inability to consistently teach a course on 
food - an area of expertise for me represented yet another opportunity cost.

Newer faculty may not face these challenges as intensely, as some of the conditions I reported have changed and other university contexts may be friendlier to food planning faculty, given the topic's greater visibility in planning. I look forward to many more faculty members earning their tenure mainly through food planning scholarship, just as I did, as the field blossoms. 


\section{Contribution \#4: Food systems coursework, from one side of the podium to the other}

Branden Born, Associate Professor, Department of Urban Design and Planning, University of Washington

Planning for food systems was totally foreign to me in 1996 when I enrolled in my required urban planning graduate studio at the University of Wisconsin. It took that semester of applied research, plus a summer editing the final document, Fertile Ground (University of WisconsinMadison, 1997), combined with a trip to the first national conference of the Community Food Security Coalition, for me to see the connections to planning and opportunities for my professional contributions. I was fortunate to be influenced by two pioneers in planning and food systems, professors Jerry Kaufman and Kami Pothukuchi.

These experiences made clear to me the importance of incorporating food systems into planning curricula, and solidified my interest in offering such a class at my eventual home institution, the University of Washington (UW). I now teach a regular biannual class entitled Urban Planning and the Food System. In 2007 I completed a two-year class project in the UW's multidisciplinary Program on the Environment (PoE) in which we worked with the City of Seattle on a food system enhancement project, funded through the Henry Luce Foundation. Focused on Seattle, the PoE class conducted a citywide food system assessment (Garrett et al., 2006) in the first year, and two neighborhood assessments and a greenhouse gas emissions life-cycle assessment of the food system in the second. The continuing class, taught in the Department of Urban Design and Planning, is more general and examines each element of the food system from production to disposal, to develop understanding of how the food system came to function as it does, and of the role of planners and policymakers in its functioning.

Inspired initially by the success of Kaufman and Pothukuchi, I nevertheless approached teaching my class with reservation - would it be accepted in my college and department? I was fortunate to find myself in an active food policy environment in Seattle. In my initial interview, the dean at the time mentioned that he had been approached by organizations focused on regional planning and sustainability and food and agriculture to seek the college's involvement. He thought my food system research, which I was relegating to a tangential focus, would be valuable to the college and, more broadly, to the region. Additionally, as a junior faculty member, I teach mostly larger service courses, which potentially gave me leverage when it came to proposing a new class that supported my interest area. It was only mildly challenged, as any new course would be, and was readily accepted by the faculty of my department.

As it turned out, the class was easy to fill; I wanted 12 students but allowed 15 to enroll, eventually losing three after the first week of course shopping. To advertise the class, I emailed the college and placed flyers about the course around the building, as is customary for our college. The second time it was offered, it filled simply by being listed in the university course catalog. Both offerings had students from outside the department and college.

The class contributes to the departmental curriculum in several ways. Primarily, it builds knowledge of food systems for future professionals, offering a marketable skill set and connections for future job opportunities. One student started working for the local affiliate of the national food bank, Feeding America, and another went on to start her own organic farm, marketing to Seattle residents. A third went to work for a community in eastern Washington (where large-scale wheat farming is common), where she found herself working frequently on food and agriculture topics. Three additional Ph.D. students have incorporated food 
systems research into their studies and publication efforts.

The class also fills a demand niche. Students in our department are very interested in the linkages between planning and the food system: in a student survey to determine what students wanted for their required concentrations, the responses mentioned seven different concentrations (the department formally offers five), including three students who wanted to specialize in food systems planning. Recent articles on planning and food systems, in addition to an increasing amount of national and local press on food issues, have raised student awareness about the importance of understanding food system processes. The class has become something that the department can sell as a special offering, making the program more attractive in a competitive landscape of planning schools.

Generally, the class complements other classes in the department and competes little, so faculty passively support it. The fact that food systems issues continue to emerge in the literature has helped build its legitimacy, and as these issues are raised locally or within the department, I have become the go-to faculty member in the department. Students have also benefited beyond the pedagogy and long-term job opportunities through a variety of funded and non-funded research and teaching opportunities. I have been fortunate for the ongoing support of my departmental, college, and outside programs such as the Program on the Environment. Washington has proven to be fertile ground for this work thus far.

Finally, the class helps to prepare students to think about the emerging issues for society generally and planning specifically. As a field, planning is designed to consider the long-term perspective. As sustainability and large issues such as global climate change and global health come to the fore, planners need to be aware of the sea change and move beyond limited considerations of land use or design and begin applying those skills to a broader set of more global considerations. The class teaches students how to systematically address a new topic, and how to bring the characteristic skills and tools of a field to bear on understanding it. This skill alone is valuable, regardless of the food and planning context.

Students in the class have been quite motivated and interested in food in a variety of ways. This is both beneficial and challenging: beneficial, because the level of knowledge on individual topics has been fairly high; challenging, because sometimes students have been less interested in topics outside their interest or specialty. For example, students interested in the development of the emergency or anti-hunger network in the US might be significantly less interested in learning about global trade regulations affecting food. This interest variability is, however, a problem in almost every class; and nontraditional or new topics may be particularly subject to it because students are even more likely to enter the class with limited or preconceived notions than they might in traditional coursework.

The class was run in a traditional seminar format, with student teams leading discussion on weekly assigned readings. There were field trips to visit food system locations throughout the region. The major assignment was a client-driven paper that assisted a local food system entity. This service learning approach is common to my other planning coursework, and as I have a broad view of planning form and function, I treat food systems planning as a natural part of the field.

My experience as a student helped me in developing the course and building legitimacy in my expertise in the subject area. I had some understanding of the transformation people can go through - from skeptical of food system relevance to very supportive of a planning role. The research we did for my graduate studio continues to function as a baseline of comparison and has helped me understand my professional research and service activities in ways I did not recognize at that time. I was lucky to enter a place that is very conscious of food system issues from quality to farmers' markets (especially as Seattle is home to the famous Pike Place Market) to urban growth patterns and the effects of land use regulations. My 
interest and primary focus on land use and public decision making and the planning process has been nicely manifested in my food system studies, and the ripeness of the issue locally has allowed my university role to flourish as I have had strong connections on the development of food policy in the city and county. My fifteen-year connection to food systems planning has certainly contributed to my success both in the academy and in application. 


\section{Contribution \#5: Reflections on teaching food system planning and policy}

Kristina Bouris, Community Planner, City of Victoria, Victoria, British Columbia

The University of British Columbia's School of Community and Regional Planning (SCARP) offered the course Food System Planning and Policy in the spring of 2005. The course was proposed, developed and taught by Wendy Mendes and myself, working at that time as professional social planners with the city of Vancouver's newly established Food Policy staff team. In addition to practicing as planners, we were both completing our respective graduate studies on municipal food policy at the time. This dual role, of the planner straddling the realms of professional practice and academic theory, would become a guiding theme of the course.

The primary goal of the course was to articulate and critically analyze issues related to planning for local food systems. Where other graduate food system planning courses explore the valuable planning contributions from grassroots activity and civil society, this course was explicit in its focus on the role of local government planners. Expanding on the work of Pothukuchi and Kaufman (1999, 2000), we asked: what could local government planners "do" to facilitate local food systems? And, most significantly, what does it take to get the food system on the municipal agenda in the first place?

The course took an integrated view of the food system, drawing links from agricultural production through to the disposal of waste. It focused primarily on the urban environment, but also included a section on planning for rural agriculture. We showcased the work of fellow planners involved in food system activities. Among our guests were a policy planner, social planner, neighborhood planner, land-use planner, rural planner, and an environmental planner, collectively making the point that the food system cuts through the silos of traditional municipal planning practice.
The course was framed squarely within the context of sustainability, a unifying theme that forms the foundation of SCARP's curriculum (and the instructors' respective research). The sustainability framework provided the freedom to explore a broad range of sub-themes related to the food system, from urban poverty to green design, from globalization to land-use conflict. Although most students possessed a sophisticated understanding of both sustainability and the food system going into the course, the same could not be said for their understanding of municipal planning practice. Knowing this ahead of time, the course was designed to use the food system as a vehicle to teach students about the legislative, political and institutional context of local government in Canada, and the tools and techniques available to planners, regardless of the issue at hand. Several students remarked that this was the first course in which someone had actually explained zoning to them. We spent a lot of time on the basics, explaining the roles and responsibilities of local government planners. It is hard to argue that planners should "do" more for the food system if there is little understanding of what planners "do" in the first place.

We took a critical look at some of the underlying forces that shape food system planning. In particular, special attention was paid to the broader governance context within which planners work, including the role that politicians, community members, governing institutions, and other actors play in shaping planning agendas and processes. Specifically, the course examined the links between urban food systems and governance and policymaking at the local scale.

A combination of politics and pressure and timing determine whether the food system makes it into the planning agenda (Bouris, 2005); it could be said 
that these same conditions determine whether a food system planning course makes it to the planning school agenda. The initial inspiration for the class grew out my collaboration with Wendy Mendes at the City of Vancouver, and our mutual interest in sharing the exciting research and initiatives with future planners. I proposed the course informally to SCARP's director in the fall of 2004, and he expressed tentative interest, pending budget decisions. The first class was held in May 2005. From my perspective, a number of conditions facilitated the course:

- A planning school with an explicit mission to "advance the transition to sustainability planning", and a (now former) director and faculty who supported that mission. By framing this course with a sustainability lens, it was a relatively "easy sell".

- A school with a culture of innovation and experimentation that has mainstreamed many non-traditional planning issues (e.g., Multimedia and Planning, PostSustainability Planning, Community Economic Development, Social Policy and Ecological Footprint Analysis).

- A school with a strong tradition of hiring local government and private sector planners as sessional instructors, thereby valuing the academic contributions of practitioners.

- Familiarity with the interests of students, faculty and the director (important in the marketing and design of the course), as I was a recent graduate of the planning program.

- A school director who had recently become knowledgeable about food system planning and policy through supervising one of the instructors' research (mine).

- A group of students interested in sustainability and food issues who effectively lobbied the director for the course, right up until the final decision.

- Finally, on a practical level, a course that was proposed as an intensive, three-week, evening/weekend course during the summer session, a season when the school offered few other courses.

From my outside vantage point as a one-time sessional instructor, ${ }^{18}$ it is difficult to determine which conditions are most important. The support of the director was central to many of these factors. It must be noted that the staging of this course faced a significant challenge due to uncertain funding. In fact, final confirmation came only in March, 10 weeks before the course was to start. In our desire to offer the class, we agreed to be paid less than the usual instructor's wage.

Looking back, I am honored to have worked with such a motivated group of students and fellow planners, and within a school that understands the food system's contributions to planning for sustainability. The course Food System Planning and Policy provided an opportunity to explore the delicate forces that create and shape an emerging planning issue. In response, planners need an understanding of complex, high-level, heady issues, as well as a firm grasp of the tools, techniques, processes and dynamics in their midst. Planners are already involved in the food system; given the right conditions, they are well positioned to do much more.

\footnotetext{
18 Authors' note: The course has been offered almost every year since by Wendy Mendes.
} 


\section{Contribution \#6: Teaching Food as an Essential Element of a Sustainable Place \\ Timothy Beatley, Teresa Heinz Professor of Sustainable Communities, Department of Urban and Environmental Planning, School of Architecture, University of Virginia}

Since 2006, Tanya Denckla Cobb and I have taught a community food systems class, both as a substantive introduction to the theory and practice of community food planning and as a hands-on workshop class applying these ideas and theories to our own local region. The reflections in this piece concentrate on the first three years of offering this course.

The focus of the course also rotates though one of three foci: community food assessment, local food policy, and global food issues. In the first year, students focused on taking stock of the greater Charlottesville food system - and preparing a comprehensive assessment of this system. The second year had an explicit policy focus, with students emphasizing specific and promising policy topics - how to create a farm-to-school program, what would be needed to transform vacant land in the city into urban farms, in what ways could production of food take place at the university itself, and how and through what means could local farmers more effectively connect with local consumers (including, for instance, the proposal of a local food distribution center). Each project team was required to do some analysis, of course, but the explicit aim was to recommend policy that could bring these ideas to fruition, and to identify important obstacles that exist and that public policy and planning might help to overcome. The third year shifted the focus to the global scale, leading students to figure out where Charlottesville's food comes from, conducting nine different case studies to discern how to better balance global and local supplies. The students (and instructors) learned much, to be sure, and there are many good ideas about how our city and region can move in the direction of a more sustainable local food system.
But probably even more important, and somewhat more surprising, have been the beyond-class outcomes, the things that have been put in motion in one way or another: the catalytic effects of the courses. At the end of the first class, we arranged for the students to present their findings at city hall, and the turnout was impressive. At the end of the student presentations, the group in attendance collectively shrugged "what do we do now," and on the spot a new local food organization was hatched. Called E.A.T. Local (Everyone at the Table), this group met for several years, and continues to function as an important virtual community and communication vehicle, helping to hatch a number of local food projects and initiatives. The classes, moreover, have resulted in local media coverage, newspaper stories, and have laid the groundwork for a highly successful state “food summit" convened in May 2007. Food courses and teaching such as this seem especially potent as community catalysts.

I have also learned that sustainable food and community food systems are wonderful avenues for teaching about community sustainability and sustainable place-building. Our planning department explicitly embraces sustainability as a value and goal, and as an important lens through which we view our entire curriculum. Food, as we know, provides entry to every aspect of community sustainability: unsustainable land use practices, energy consumption and fossil fuel dependence, public health and the obesity crisis, opulence and unsustainable consumption, among others. And it allows the chance to tangibly explore and advocate more sustainable lifestyles that need not be sacrificial, but rather are inherently richer, fuller, more healthy. Sufficiency and sustainability look pretty appealing when in the form of a rhubarb confit or local blueberry pie. 
Reinvigorated local sustainable food systems, moreover, represent for me a potentially powerful form of community building, and a way to profoundly strengthen and revive our place commitments. Much of my own recent work has focused on creative ideas and practice for overcoming our increasing disconnect from people and landscapes, and for re-building a strong culture of place rootedness (e.g. Beatley, 2004). Rethinking food represents to me an important way of responding to our special crisis of place, as global pressures towards homogeneity and sameness undermine many of the unique and special qualities of actual places, as well as the personal relationships and networks that bind people together and to the landscapes they live in. Reviving more locally based sources of food, reconnecting local food producers with local consumers, looking for creative ways of allowing local residents to grow (together) at least some of their own food, and rediscovering the food heritages of a community or region, among other ideas, offer tremendous potential to re-build place and community and to reconnect people to landscapes and to each other. Teaching community food planning then, for me, becomes a way of teaching about place-building, understanding that to advance food security will at the same time deepen place commitments, and in these ways are natural extensions of my usual teaching and scholarship.

One of the most important lessons for me from these recent food forays is that the educational potential of food goes considerably beyond the specific topics and substantive teaching of a community food systems class. We discovered in our department that sustainable food issues have opened a window for all of our students, not just those self-described "foodies" who take our classes. The power of food as a way of connecting us to place and to making tangible sustainability issues and concerns was especially brought home to me in the fall of 2006 when our department embarked on an interesting and unusual experiment. During the previous summer, I had had the opportunity to meet and interview in Vancouver Alicia Smith, a talented author and, along with her partner, a passionate advocate for local food and creator of the 100-mile diet (Smith \& MacKinnon, 2007). I got a sense of how their experiment of living an entire year eating only foods grown within 100 miles of her home has helped transform her own city and community for her.

Later that same summer Alicia emailed me with a proposal. They were organizing a 100-mile Thanksgiving meal, and she wondered whether UVA would like to join the campaign. I thought it was a terrific approach to introducing sustainable and local food issues to the entire faculty and planning student body. After allaying some concerns about whether such a thing was feasible and even desirable (several students worried that this meant they could not utilize traditional spices and ingredients that they fondly associate with Thanksgiving), most of the angst seemed to center around the extra planning and thinking that might be required. Students could not just zip by the Giant or Harris Teeter and pick up a bag of chips and salsa. This was a terrific and helpful message in itself, and in the end the entire planning department embraced the concept with an incredible level of energy and positive enthusiasm. I incorporated the event and issues into my fall Sustainable Communities class, requiring each student to research a local food and to contribute a Thanksgiving recipe utilizing locally grown ingredients. I further incorporated a similar section on food in my much larger lecture Introduction to Community and Environmental Planning class (about 200 students) and challenged the students to think about how they might encourage their parents to organize a 100-mile Thanksgiving, or at least to be more conscious that year about the sourcing of food. The initial joke about our departmental dinner was that we were going to be drinking a lot of wine - Central Virginia is a burgeoning area of wineries and vineyards - and apples. But in the end the group presented a rich and diverse offering, from locally grown and stored potatoes and greens to turkeys from local farmer Joel Salatin's Polyface Farm, now somewhat famous as a result of Michael Pollan's book The Omnivore's Dilemma (2006). 
We all learned to think more carefully about seasonality as well, planning our meals around it. We also learned as a department what the present limitations are to eating locally, again something that our "foodies" were aware of but the broader group of students and faculty probably weren't. We discovered a historic mill, Wade's Mill, within our 100-mile radius, that sells flour and cornmeal from locally grown grains - a business that many of us continue to support. We also learned that finding local milk was very difficult (surprising to many, as local dairies had been at one time a ubiquitous connection between local landscapes and residents), though we fudged the 100-mile limit a bit to be able to use milk from a dairy in the Shenandoah Valley, just over the line.

We have now organized five such dinners, and the 100-mile Thanksgiving has become a regular and much-anticipated event in our department and school. Each year the students have added new activities and pre-dinner events, which have included canning workshops, visits to local farms, and, a few days before the event, a kind of pilgrimage to Polyface Farm to pick up the turkeys. The students and faculty take this Thanksgiving event and the challenge and opportunity to learn the issues behind it very seriously. Perhaps they are too serious at times: One year, Student Planners Association officials sent out an email that all dishes should be accompanied with a small placard or card indicating the estimated percentage of the ingredients that were derived from within 100 miles. These people I humorously dubbed the "local food police" and though the suggestion might have been a tad too regulatory and rigid for my taste, it was certainly interesting and educational to see the plates and dishes arrayed on tables with full geographical disclosure!

The challenge of sourcing and eating local food also opened up other new vistas and perspectives on place and home. I had wondered about our Native American heritage, and wanted in some way to use our food and Thanksgiving as a temporal connection to the Monacans, the indigenous inhabitants of our central Virginia environment, who had stewarded this land for some 10,000 years before the European settlers arrived. They are given remarkably little acknowledgement or visibility in Charlottesville, which is proud of the three presidents who called the region home (including of course Thomas Jefferson, founder of the University of Virginia). My nod to this heritage came in the form of collecting from the grounds of the university white oak acorns (sweeter and with lower levels of tannic acid), and attempting to make acorn flour and then acorn bread. The bread yielded an unusual but delightful flavor, something I had never tasted before, made all the more special because of the connection with the history and biodiversity of my place on earth.

The lessons from this event have been many and impressive. Students and faculty alike learned much (and I certainly did, even as a 20-year resident) about our community and region, and we developed new personal connections with farmers and producers. It has been refreshing to see newly arrived graduate students join local CSAs and passionately support our increasingly vibrant farmers market, discovering their own roles as genuine members of a community, with real corresponding duties and commitments, and not just as temporary visitors (perhaps that is part of our problem: too many students never shed this ephemeral and superficial view of the places in which they reside). We all collectively learned, I think, to look at our home in a new way, and hopefully this newfound consciousness has helped to solidify our collective commitments to the landscape and to a community that ultimately sustains itself. 


\section{Contribution \#7: Teaching Food in Rome}

Barbara Lynch, Professor, Sam Nunn School of International Affairs, Georgia Institute of Technology [formerly at Cornell University]

Visitors are drawn to Italy's landscapes, its historic legacy, and especially its food. Planning students and faculty in Cornell-in-Rome were no exception. Cornell's Rome Program serves undergraduate students in architecture, art, and planning, along with a small number from the humanities and social sciences. The core course for planners in Rome is a workshop in which students gather data on a small set of topics in three or four neighborhoods outside the historic center. The curriculum varies from year to year, but in general, the core course is complemented by course offerings on the Italian regions and on Italian politics and society and by travel to other parts of the country.

When we arrived in 2001 for that summer's planning workshop, we found market stalls piled high with fresh, local produce; myriad bakeries, butcher shops, pizzerias, and dairies; and superb trattorie scattered throughout Rome's historic center - outward signs of what seemed to be an outstanding food system. We were impressed by the unusual interdigitation of urban and rural landscapes: on the ancient Appian Way we found orchards and sheep, and in several Roman neighborhoods we found vegetable gardens and livestock. We also learned of Roman food concerns, from mad cow disease to the impacts of European agricultural policies on Italian foods and the closing of the wholesale produce market in Ostiense. When we studied Torre Spacata, a postwar neighborhood on the edge of Rome, we saw few signs of the robust food system that characterized the center. So, when the 2001 semester ended, I concluded that inequality of access to good quality food could be an important issue for planners and a fascinating entry point for the core workshop.
Five years later, I returned to the eternal city with a new group of students. By that time food planning had moved closer to the mainstream of planning concerns, the Slow Food movement had grown and gone global, new agricultural policies were redefining the agricultural roles of Italian regions, and Roman planners were paying increasing attention to the role of markets and piazze in neighborhood revitalization and to the importance of preserving agricultural landscapes close to the city. In this context, I decided to make food a central theme of the workshop this time.

The structure of the 2006 workshop made it relatively easy to relate food access issues to other planning concerns. My collaborator Greg Smith and I divided the class into four working groups, each assigned to one of three neighborhoods: San Lorenzo, Valle Aurelia, and Prima Valle. The neighborhoods lie outside the Aurelian Wall and had been countryside until the early twentieth century. Each working group was comprised of four students: one focused on parks and open space, a second on housing, a third on transport, and the fourth on food. A fifth student, attached to the Prima Valle group, worked with immigrants. Smith, a Roman resident, played a key role putting us into contact with Roman officials working with markets and food, with local planners, and even with agricultural enterprises lying within the city's boundaries. In particular, meetings with city officials gave us fascinating insights into the structure and function of Rome's public markets. Smith and I shared a preference for qualitative methods, and we encouraged the "foodies" to hang out in local supermarkets, markets, and small retail shops. They interviewed shoppers in all three locations as well as market sellers. I also took them to some other market sites in Rome, notably the 
Esquilino market, Rome's primary source of ethnic foods, recently moved to an indoor location.

Our work in Rome was complemented by trips to Sicily and Piedmont. We read about and visited Palermo's Vucceria, the fabulous fish market in Catania, and Torino's extensive covered and open market, which serves an ethnically diverse population. We also met with Slow Food organizers in Bra and members of the Piedmontese cattle "Presidio" on their farms. ${ }^{19}$ In short, by the end of the course, we had met with food producers, retailers, consumers, food activists, and regulators. A missing link was the new Rome wholesale market, large portions of which were closed to visitors, but even without such a visit, we learned a great deal about the Roman and Italian systems, ending the semester less optimistic about the future than we might have been.

After studying San Lorenzo, Prima Valle and Valle Aurelia in some depth, we were less convinced that differential access to fresh food was the major question, although it remained an important one. The three neighborhoods were by and large working-class neighborhoods whose character was changing with rising housing prices and an influx of students and immigrants. All three were well served by supermarkets and retail shops. San Lorenzo and Primavalle had ample public markets as well. Only Valle Aurelia suffered in this regard: its weekly market was located on the urban edge, and it had only three fresh produce stalls.

Differences between neighborhoods were less apparent than the problems faced by particular subgroups within each neighborhood. Because the student groups were also asking about transportation, housing, and changing demographics, they became increasingly aware of the relationship between parking and food, and students were sensitized to the problems that the elderly faced in places served largely by

19 "Presidio" literally means fortress. Slow Food has adopted this term to refer to the protection of particular cultivars, livestock races, and/or methods of production by producer groups and the validation of their methods. supermarkets or public markets on the edge of the neighborhoods. They also noted that public markets, open from 9 am to $2 \mathrm{pm}$, were of little use to working women. As outsiders living and cooking in Rome, students in the course became acutely aware of the key roles that immigrants played in food retailing and of the degree to which the food system met the needs of Rome's diverse ethnic groups - a topic that has received little attention from planners and sociologists. ${ }^{20}$

Our investigations raised concerns about the continuing viability of the Roman food system, with changes in the commodity chains that link producers to consumers. Of particular concern was the diminishing importance of the public market in the food system. Markets flourished in a society where many sellers had intimate connections to the countryside and where the wholesale market was close to retail markets. In this context, commodity chains were relatively short and potentially responsive to consumer demand. In $21^{\text {st }}$ century Rome, these chains seem longer and more tenuous.

Our investigations coincided with the approval process for Rome's Master Plan. Students used planning documents and statistics provided by the city to learn more about agricultural land preservation policies. In this area, they were encouraged by positive statements about the ecological and landscape value of agriculture in the Roman countryside. In their neighborhood investigations of open space, they charted the presence of community gardens and livestock facilities on public land. Face-to-face encounters with animals in the city and discoveries of fava beans growing behind fences were some of the more delightful experiences of the field work, although we were surprised by the absence of a community garden movement and by the relatively underdeveloped state of organic product marketing.

\footnotetext{
${ }^{20} \mathrm{~A}$ handful of studies do exist in this area. See, for instance, Lynch (2005) on Latino gardens in New York and the Northeast, or the work of Alfonso Morales $(2007,2009)$ on markets in Los Angeles.
} 
At the end of the day, all students in the workshop — not just the "foodies" — had a greater appreciation of how food moves from producer to consumer, and what happens to it along the way. Todd drew on his work in the workshop for an honors thesis on changing patterns of food retailing in Rome. Ed, a big guy who shared Bill
Clinton's former passion for fast food, came away vowing to start a fast-food outlet for Slow Food. On the whole, the class seemed to have gained a new consciousness about the centrality of food to national culture, social integration, and well-being. If nothing else, they are better cooks and smarter shoppers. 


\section{References}

American Planning Association, Legislative and Policy Committee. (2006). Food system planning white paper. Washington, D.C.: APA Food System Planning Committee. Retrieved from http://www.scribd.com/doc/34476977/ProposedWhite-Paper-on-Food-System-Planning

American Planning Association. (2007). Policy guide on community and regional food planning. Washington, D.C.: APA. Retrieved from http://www.planning. org/policyguides/pdf/food.pdf

American Planning Association. (2011). Planning for food access: A national scan and evaluation of local comprehensive plans. Washington, D.C.: APA Planning and Community Health Research Center. Retrieved from http://www.planning.org/ research/foodaccess/index.htm

Argenti, O. (2000). Food for the cities: Food supply and distribution policies to reduce urban food security. A briefing guide for mayors, city executives and planners in developing countries and countries in transition. Rome: Food and Agriculture Organization of the United Nations, Food into Cities Collection, DT/43-00E.

Beatley, T. (2004). Native to nowhere: Sustaining home and community in a global age. Washington, D.C.: Island Press.

Bouris, K. (2005). Examining the barriers and opportunities to local food system planning in the Georgia Basin: Of planners, politics and the public. (Unpublished master's thesis). University of British Columbia, School of Community and Regional Planning https://circle.ubc.ca/bitstream/handle/2429/ 16248/ubc 2005-0012.pdf;jsessionid $=012588 \mathrm{E}$ DD04F33D20087E8AF3C560D0A? sequence $=1$

Centre for Studies in Food Security, Ryerson University. (2008, 2-4 May). The Role of Food and Agriculture in the Design and Planning of Buildings and Cities: $A$ Symposium. Ontario: Ryerson University. Retrieved from http://www.ryerson.ca/foodsecurity/ projects/ urbandesign/ presentations.html

Dahlberg, K. A. (1994). Food policy councils: The experience of five cities and one county. Presented at the Joint Meeting of the Agriculture, Food and Human Values Society and the Society for the Study of Food and Society, Tucson, Arizona.

Dahlberg, K. A. (1999). Promoting sustainable local food systems in the United States. In M. Koc, R.
MacRae, L. J. A. Mougeot, \& J. Welsh, (Eds.), For bunger-proof cities: Sustainable urban food systems. Ottawa: International Development Research Centre.

Dubbeling, M. (2001). A framework for facilitating planning and policy. Urban Agriculture Magazine, 5, Topic Paper 2. Retrieved from http://www.ruaf.org/node/196

Food and Agriculture Organization of the United Nations. (1998). Feeding the cities. Excerpt from: The state of food and agriculture. Rome, IT: Food and Agriculture Organization of the United Nations. Food into Cities Collection DT/39-98E.

Food and Agriculture Organization of the United Nations. (2000). Seminar addresses feeding Asia's cities. FAO News Highlights. November 23. Rome, IT: Food and Agriculture Organization of the United Nations. Retrieved from http://www.fao.org/english/newsroom/ highlights/2000/001102-e.htm

Foodplanning - urban planning and food systems. (n.d.). Listserv based at the University of Washington. http://mailman1.u.washington.edu/ mailman/listinfo/foodplanning

Garrett, S., Naas, J., Henze, T., Keithly, S., RadkeSproull, S., \& Watterson, C. (2006). Sound food report: Enhancing Seattle's food system. Seattle, Washington: University of Washington. Retrieved from http:// faculty.washington.edu/bborn/Sound Food Report2.pdf

Gorgolewski, M., Komisar, J., \& Nasr, J. (2011). Carrot city: Creating places for urban agriculture. New York, New York: Monacelli Press.

Hammer, J. (2004). Community food systems and planning curricula. Journal of Planning Education and Research, 23(4), 424-434. http://dx.doi.org/10.1177/0739456X04264907

Hodgson, K., Campbell, M. C., \& Bailkey, M. (2011). Urban agriculture: Growing healthy, sustainable places. Planning Advisory Service (PAS) Series, No. 563. Chicago, Illinois: American Planning Association.

International Development Research Centre (IDRC) and Urban Management Program for Latin America and the Caribbean (UMP). (2003). Guidelines for municipal policymaking on urban agriculture. Retrieved from http://www.idrc.ca/en/ev-29688201-1-DO TOPIC.html 
Kaufman, J., \& Glosser, D. (2006a). The food system: A new addition to the planning field. The Commissioner, $1-2$.

Kaufman, J., \& Glosser, D. (2006b). Food system planning: Why is it a planning issue? Environmental Planning Newsletter, 3-6.

Komisar, J., Nasr, J., \& Gorgolewski, M. (2009). Designing for food and agriculture: Recent explorations at Ryerson University. Special issue: Designing Edible Landscapes. Guest Ed. Bhatt, V. Open House International, 34(2), 61-70.

Lang, T. (1999). Food policy for the 21st century: Can it be both radical and reasonable? In M. Koc, R. MacRae, J.A. Mougeot, J. Welsh. (Eds.) For hungerproof cities: Sustainable urban food systems. Ottawa, Ontario: International Development Research Centre.

Lawson, L.S. (2005). City bountiful: A century of community gardening in America. Berkeley and Los Angeles, California: University of California Press.

Linder, M., \& L.S. Zacharias. (1999). Of cabbages and Kings County: Agriculture and the formation of modern Brooklyn. Iowa City, Iowa: University of Iowa Press.

Lynch, B. (2005). Nature, memory, and nation: New York's Latino gardens and casitas. In P. Barlett. (Ed.). Urban place: Reconnecting with the natural world. Cambridge, Massachusetts: MIT Press.

Mendes, W. (2006). Creating a "just and sustainable" food system in the city of Vancouver: The role of governance, partnerships and policymaking (Unpublished doctoral thesis). Simon Fraser University. Department of Geography.

Mendes, W. (2007). Negotiating a place for "sustainability" policies in municipal planning and governance: The role of scalar discourses and practices. Space \& Polity, 11(1), 95-119. http://dx.doi.org/10.1080/13562570701406683

Mendes, W. (2008). Implementing social and environmental policies in cities: The case of food policy in Vancouver, Canada. International Journal of Urban and Regional Research, 32(4), 942-967. http://dx.doi.org/10.1111/j.14682427.2008.00814. $\mathrm{x}$

Mendes, W., Balmer, K., Kaethler, T., \& Rhoads, A. (2008). The role of urban agriculture in enhancing green communities: Experiences from Portland, Oregon and Vancouver, British Columbia. Journal of the American Planning Association, 74(4), 435-449. http://dx.doi.org/10.1080/01944360802354923

Morales, A. (2009). A woman's place is on the street: Purposes and problems of Mexican American women entrepreneurs. In J. S. Butler, A. Morales, \& D. L. Torres, (Eds.). An American story: Mexican American entrepreneurs and wealth creation. West Lafayette, Indiana: Purdue University Press.

Morales, A. (2007). Conclusion: Law, deviance, and defining vendors and vending. In J. Cross, \& A. Morales, (Eds.). Street entrepreneurs: People, places, and politics in local and global perspective. London: Routledge.

Morgan, K., Marsden, T., \& J. Murdoch, J. (2006). Worlds of food: Place, power and provenance in the food chain. Oxford Geographical and Environmental Studies Series. Oxford, UK: Oxford University Press.

Morgan, K., \& Sonnino, R. (2008). The school food revolution: Public food and the challenge of sustainable development. London: Earthscan.

Mougeot, L. (1994). The rise of city farming: Research must catch up with reality. ILEIA Newsletter, 10(4), 4-5.

Mougeot, L. (2000). Urban agriculture: Definition, presence, potentials and risks. In N. Bakker, M. Dubbeling, S. Gründel, U. Sabel-Koschella, \& H. de Zeeuw. (Eds.) Growing cities, growing food. Feldafing, DE: Deutsche Stiftung für Entwicklung.

Nasr, J., \& Komisar J. (In press). Integration of food and agriculture into urban planning and design practices. In A. Viljoen \& H. Wiskerke. (Eds.). Sustainable food planning: Evolving theory and practice. Wageningen, NL: Wageningen Academic Publishers.

People's Food Policy Project. (2009). Canadian food policy organisations. Retrieved from http://www.peoples foodpolicy.ca/canadian-food-policy-organisations

Planning for Agriculture \& Food Network. (n.d). http://groups.google.com/group/planning-foragriculture-and-food-network-pafn?hl=en

Planning for Food. (2006). Post World Congress Seminar, June 21, 2006, Vancouver. Ministry of Agriculture and Lands, Government of British Columbia, Canada. Retrieved from http://www.agf.gov.bc.ca/resmgmt/sf/ plan food/pl food 0606.htm 
Pollan, M. (2006). The omnivore's dilemma: A natural history of four meals. New York, New York: Penguin.

Pothukuchi, K., \& Kaufman J. (1999). Placing the food system on the urban agenda: The role of municipal institutions in food systems planning. Agriculture and Human Values, 16(2), 213-244. http://dx.doi.org/10.1023/A:1007558805953

Pothukuchi, K, \& Kaufman J. (2000). The food system: A stranger to the planning field. Journal of the American Planning Association, 66(2), 112-124. http://dx.doi.org/10.1080/01944360008976093

Progressive Planning. (2004). Special Issue: Food and Planning. No. 158. Retrieved from http://www.plannersnetwork.org/publications/ mag_2004_1_winter.html

Quon, S. (1999). Planning for urban agriculture: A review of tools and strategies for urban planners. Cities Feeding People Series, Report 28. Ottawa, Ontario: International Development Research Centre.

Raja, S., Born, B., \& Kozlowski-Russell, J. (2008). A planner's guide to community and regional food planning: Transforming food environments, building healthy communities. Planning Advisory Service (PAS) Series, No. 554. Chicago, Illinois: American Planning Association.

Ratta, A., \& Nasr, J. (1996). Urban agriculture and the African urban food supply system. African Urban Quarterly, 11(2/3), 154-162.

Rocha, C. (2001). Urban food security policy: The case of Belo Horizonte, Brazil. Journal for the Study of Food and Society, 5(1), 36-47. http://dx.doi.org/10.2752/152897901786732735

Schiff, R. (2007). Food policy councils: An examination of organisational structure, process, and contribution to alternative movements (Unpublished doctoral thesis). Murdoch University, Western Australia.
Smit, J., Nasr, J., \& Ratta, A. (2001). Urban agriculture: Food, jobs and sustainable cities. Unpublished $2^{\text {nd }}$ edition. New York: United Nations Development Programme. Available at http://www.jacsmit.com/book.html

Smith, A., \& MacKinnon, J. B. (2007). The 100-mile diet: A year of local eating. Toronto, Ontario: Random House Canada.

Stanhill, G. (1976). An urban agro-ecosystem: The example of nineteenth-century Paris. Agro-

Ecosystems, 3, 269-284.

http://dx.doi.org/10.1016/0304-3746(76)90130-X

Steel, C. (2008). Hungry city: How food shapes our lives. London, UK: Chatto \& Windus.

University of Wisconsin-Madison. Department of Urban and Regional Planning. (1997). Fertile ground: Planning for the Madison/Dane County food system. Madison, Wisconsin: University of Wisconsin.

Viljoen A., Bohn, K., \& Howe, J. (Eds.) (2005). CPULs - Continuous Productive Urban Landscapes: Designing urban agriculture for sustainable cities. Oxford, UK \& Burlington, Massachusetts: Architectural Press/Elsevier.

Wakefield, S., Yeudall, F., Taron, C., Reynolds, J., \& Skinner, A. (2007). Growing urban health: Community gardening in Southeast Toronto. Health Promotion International, 22(2), 92-101. http://dx.doi.org/10.1093/heapro/dam001

Welsh, J., \& MacRae, R. (1998). Food citizenship and community food security: Lessons from

Toronto, Canada. Canadian Journal of Development Studies, 19, Special Issue: The quest for food security in the twenty-first century, 237-255.

Wekerle, G. R. (2004). Food justice movements: Policy, planning, and networks. Journal of Planning Education and Research, 23(4), 378-386. http://dx.doi.org/10.1177/0739456X04264886 